\title{
Store blodpropper i hjernen bør fjernes med trombektomi
}

\author{
Flere studier har i 2015 vist at trombektomi ved akutt hjerneinfarkt gir bedre gevinst enn trombolytisk \\ behandling. Store internasjonale organisasjoner har endret sine anbefalinger i tråd med dette. Også i Norge \\ jobbes det nå med implementering av metoden som standardbehandling for pasienter med påviste okklu- \\ sjoner i hjernearteriene.
}

«Tid er hjerne». Det er ingen tvil om at tidligst mulig rekanalisering av en okkludert arterie er grunnleggende for å redusere hjerneskaden ved akutt hjerneinfarkt (1).

Intravenøs trombolytisk behandling med alteplase ble i 2003 godkjent som basal akuttbehandling i Norge og gis innen fire og en halv time etter symptomstart. Men effekten av intravenøs alteplase er begrenset. Særlig der det foreligger store, organiserte propper som okkluderer større hjernekar proksimalt i kartreet, er behandlingseffekten bare ca. $30 \%$ (2). Denne type okklusjoner utgjør mer enn en tredel av hjerneinfarktene bare i den fremre sirkulasjonen (2).

\section{Akuttbehandling i rask utvikling \\ De senere år har det vært en eskalering $\mathrm{i}$ behandlingen av akutt hjerneinfarkt. Blant annet tester man i to norske multisenterstu- dier nå effekten av trombolysepreparatet tenecteplase (NOR-TEST) (3) og effekten av kontrastforsterket sonotrombolyse med \\ «Trombektomi er kunnskapsbasert behandling»} intravenøs mikroboblekontrast (NORSASS) (4). Et alternativ til systemisk trombolytisk behandling er å nærme seg proppen intraarterielt og levere trombolysemedikamentet direkte til okklusjonsstedet (intraarteriell trombolytisk behandling). Dette er en tidkrevende, kjemisk prosess. Derfor har det å fjerne proppen mekanisk blitt den anbefalte metoden (intraarteriell trombektomi) $(5,6)$.

De kliniske resultatene av de første store trombektomistudiene publisert i 2013 viste ingen forskjell mellom trombektomi og intravenøs trombolytisk behandling og var dermed skuffende (7-9). Men høsten 2014 ble MR CLEAN-studien publisert. Her brukte man moderne uthenterstenter (stent retrievers) som raskt åpner arterien (stent) og så henter ut proppen (retriever) fremfor tidligere generasjoners rene uthentere. Studieinklusjonen krevde en proksimal karokklusjon i fremre kretsløp påvist ved angiografi, og behandlingen ble utført innen seks timer etter symptomdebut. MR CLEANstudien var den første studien som viste en klart bedre effekt av intravenøs trombolytisk behandling kombinert med intraarteriell trombektomi sammenlignet med intravenøs trombolytisk behandling alene. Effekten var til stede for samtlige primære og sekundære endepunkter, som inkluderte både klinisk resultat og radiologiske variabler (10): Etter gjennomført trombektomi oppnådde flere pasienter forbedret funksjonelt resultat målt ved modifisert Rankin-skala etter 90 dager. Kliniske symptomer målt ved NIH Stroke Scale etter 24 timer og deretter en uke var mildere, og rekanalisering etter 24 timer og etablert infarktstørrelse etter en uke var forbedret. Etter 90 dager var mortalitet og opptreden av symptomatiske cerebrale blødninger lik i begge behandlingsarmer.

I 2015 er det publisert tilsvarende positive data fra ytterligere fire internasjonale trombektomistudier (11-14). Flere studier er på vei, og lovende data fra disse ble presentert på European Stroke Organisation Conference i Glasgow i april. I fire av de

fem publiserte nye studiene ble trombektomi utført innen seks timer etter symptomdebut, og i samtlige studier brukte man moderne uthenterstenter, som per i dag er standardutstyret for mekanisk trombektomi. Resultatene fra disse nyeste studiene viser at okklusjoner i intrakraniale arteria carotis interna eller proksimale arteria cerebri media-grener (M1, M2) rekanaliseres effektivt og trygt og fører til forbedret funksjonelt langtidsresultat målt ved modifisert Rankin-skala 90 dager etter behandling, sammenliknet med intravenøs trombolytisk behandling alene. Samtidig medfører intraarteriell trombektomi ingen høyere risiko for intracerebrale blødninger eller død sammenliknet med intravenøs trombolytisk behandling etter 90 dager.

European Stroke Organisation (ESO) har fulgt opp resultatene med en klar anbefaling om å supplere intravenøs trombolytisk behandling innen fire og en halv time med mekanisk trombektomi innen seks timer etter symptomdebut, uten at initiering av begge metoder forsinker hverandre. Trombektomi er videre førstelinjebehandling når intravenøs trombolytisk behandling er kontraindisert, f.eks. pga. antikoagulasjon (6). Indikasjonen omfatter påviste okklusjoner i både fremre og bakre cerebrale kretsløp. Vurderinger, intervensjon og oppfølging må foretas av et dedikert og erfarent multidisiplinært team med hjerneslagekspert, nevroradiolog, intervensjonsnevroradiolog og anestesilege, samtidig som nevrokirurgisk behandling (ekstern ventrikkeldrenasje, hemikraniektomi) må kunne gjennomføres raskt når nødvendig (6).

\section{Situasjonen i Norge}

Norsk hjerneslagforening (NSO) jobber for tiden intenst med nasjonale retningslinjer som tilpasser internasjonale anbefalinger til de logistisk krevende forholdene i Norge. Våre erfaringer fra Haukeland universitetssykehus viser at antallet pasienter som behandles med trombektomi er doblet fra år til år siden tilbudet ble innført. Dørtil-punksjon-tiden er blitt kraftig redusert, tiden fra symptomdebut til rekanalisering er blitt stadig kortere og økende erfaring med intervensjon og moderne utstyr har medført færre komplikasjoner (upubliserte data).

Det anslås at over $20 \%$ av pasientene kan være aktuelle for intraarteriell trombektomi (15). Forutsetning for behandlingen er at det påvises en okklusjon av proksimale intracerebrale kar innen det terapeutiske tidsvinduet basert på ikke-invasiv angiografi (6). Å synse om en slik okklusjon er til stede eller ikke utelukkende ut ifra kliniske vurderinger, har vist seg praktisk umulig på individnivå, og CT angiografi er derfor å foretrekke $(15,16)$. Propper bør fjernes raskt også ved tilsynelatende beskjedne kliniske funn, på lik linje som det er vist for intravenøs trombolytisk behandling (17).

En telefonrunde bekreftet at samtlige universitetssykehus i Norge utfører trombektomi. Alle gir full dose intravenøs trombolyse umiddelbart og videresender pasientene til trombektomi raskest mulig. Denne uformelle datainnhentingen antyder at i 2014 ble til sammen ca. 100 pasienter trombektomert ved universitetssykehusene i Oslo, Bergen, Stavanger, Trondheim og Tromsø. Til og med september 2015 har allerede 100 pasienter gjennomgått intraarteriell behandling i Norge.

Studiene vi har referert til i denne artikkelen (10-14) viser at trombektomi i dag er den mest effektive behandlingen for å fjerne store karokklusjoner og at metoden er trygg. CT-angiografi er nødvendig for å oppdage karokklusjoner (16) og vi mener derfor at det bør innføres som rutineundersøkelse ved alle sykehus som behandler akutt hjerneinfarkt. 
Trombektomi er kunnskapsbasert behandling. Nye studier har vist at den medisinske nytten er utvilsom, og vi mener behandlingstilbudet må økes. Helsevesenet må endres i møte med en ny virkelighet. Det haster.

\section{Annette Fromm}

atfm@helse-bergen.no

Lars Thomassen

Annette Fromm (f. 1977) er spesialist i nevrologi, med spesialkompetanse i nevrovaskulære sykdommer. Hun er postdoktor ved Nevrovaskulær forskningsgruppe, Nevrologisk avdeling. Haukeland universitetssykehus og medlem av European Stroke Organisation.

Forfatter har fylt ut ICMJE-skjemaet og oppgir ingen interessekonflikter.

Lars Thomassen (f. 1947) er spesialist i nevrologi, med spesialkompetanse i nevrovaskulære sykdommer. Han er professor ved Universitetet i Bergen, leder av Nevrovaskulær forskningsgruppe, Nevrologisk avdeling. Haukeland universitetssykehus og medlem av European Stroke Organisation.

Forfatter har fylt ut ICMJE-skjemaet og oppgir ingen interessekonflikter.
Litteratur

1. Rha JH, Saver JL. The impact of recanalization on ischemic stroke outcome: a meta-analysis. Stroke 2007; 38: 967-73.

2. Kerasnoudis A, Meves SH, Gold R et al. Correlation between frequency of microembolic signals and efficacy of antiplatelet therapy in symptomatic carotid disease. J Neuroimaging 2013; 23: 484-8.

3. Logallo N. Kvistad CE, Nacu A et al. The Norwegian tenecteplase stroke trial (NOR-TEST): randomised controlled trial of tenecteplase vs. alteplase in acute ischaemic stroke. BMC Neurol 2014; 14: 106.

4. Nacu A, Kvistad CE, Logallo $\mathrm{N}$ et al. A pragmatic approach to sonothrombolysis in acute ischaemic stroke: the Norwegian randomised controlled sonothrombolysis in acute stroke study (NOR-SASS). BMC Neurol 2015; 15: 110

5. Powers WJ, Derdeyn CP. Biller J et al. 2015 American Heart Association/American Stroke Association Focused Update of the 2013 Guidelines for the Early Management of Patients With Acute Ischemic Stroke Regarding Endovascular Treatment: A Guideline for Healthcare Professionals From the American Heart Association/American Stroke Association. Stroke 2015; 46: 3020-35.

6. ESO-Karolinska Stroke Update Conference 2014. Consensus statement on mechanical thrombectomy in acute ischemic stroke. http://2014.strokeupdate.org/consensusstatement-mechanical-thrombectomy-acuteischemic-stroke (10.11.2015).

7. Broderick JP, Palesch YY, Demchuk AM et al. Endovascular therapy after intravenous t-PA versus t-PA alone for stroke. N Engl J Med 2013; 368: 893-903.

8. Ciccone A, Valvassori L, Nichelatti M et al. Endovascular treatment for acute ischemic stroke. N Engl J Med 2013; 368: 904-13.

9. Kidwell CS, Jahan R, Gornbein J et al. A trial of imaging selection and endovascular treatment for ischemic stroke. N Engl J Med 2013; 368: 914-23.

10. Berkhemer OA, Fransen PS, Beumer D et al. A randomized trial of intraarterial treatment for acute ischemic stroke. N Engl J Med 2015; 372 $11-20$.

11. Campbell BC, Mitchell PJ, Kleinig TJ et al. Endovascular therapy for ischemic stroke with perfusion-imaging selection. N Engl J Med 2015; 372 $1009-18$

12. Goyal M, Demchuk AM, Menon BK et al. Randomized assessment of rapid endovascular treatment of ischemic stroke. N Engl J Med 2015; 372: 1019-30.

13. Saver JL, Goyal M. Bonafe A et al. Stent-retriever thrombectomy after intravenous t-PA vs. t-PA alone in stroke. N Engl J Med 2015; 372: 2285-95.

14. Jovin TG, Chamorro A, Cobo E et al. Thrombectomy within 8 hours after symptom onset in ischemic stroke. N Engl J Med 2015; 372: 2296-306.

15. Hansen CK, Christensen A, Ovesen $C$ et al. Stroke severity and incidence of acute large vessel occlu sions in patients with hyper-acute cerebral ischemia: results from a prospective cohort study based on CT-angiography (CTA). Int J Stroke 2015; 10: $336-42$.

16. Maas MB, Furie KL, Lev MH et al. National Institutes of Health Stroke Scale score is poorly predictive of proximal occlusion in acute cerebral ischemia. Stroke 2009; 40: 2988-93.

17. Kvistad CE, Logallo N, Næss $\mathrm{H}$ et al. Et ikke fullt så mildt hjerneinfarkt. Tidsskr Nor Legeforen 2014; 134: 1828-9.

Mottatt 18.9. 2015, første revisjon innsendt 26.10. 2015, godkjent 10.11. 2015. Redaktør: Lise Mørkved Helsingen.

Publisert først på nett. 